\title{
Protein Synthesis and Degradation in Anabaena During Nitrogen Starvation
}

\author{
By JAMES D. OWNBY, MARK SHANNAHAN AND \\ ELIZABETH HOOD \\ Department of Biological Sciences, Oklahoma State University, \\ Stillwater, Oklahoma 74074, U.S.A.
}

(Received 29 August 1978)

\begin{abstract}
Nitrogen starvation and heterocyst development were induced in the cyanobacterium Anabaena 7120 by growth in nitrogen-free medium or by treatment with the amino acid analogue methionine sulphoximine. During the first $6 \mathrm{~h}$ of nitrogen deprivation, amino acid levels and rates of protein synthesis, as measured by the incorporation of $\left[{ }^{3} \mathrm{H}\right]$ leucine, decreased to 50 to $70 \%$ of those in ammonia-grown organisms; after this time there was no difference between the rates of protein synthesis in ammonia-grown and nitrogen-starved cultures. The period 4 to $12 \mathrm{~h}$ after the onset of starvation was marked by the release of $\left[{ }^{3} \mathrm{H}\right]$ leucine from previously labelled proteins at a rate 6 to $7 \cdot 5$ times that of ammoniagrown organisms. These results are consistent with the idea that nitrogen starvation in cyanobacteria causes a reduction in protein synthesis and leads to the rapid degradation of storage proteins. In rapidly growing Anabaena 7120 , the doubling time for total cell protein was estimated to be $14.9 \pm 1.0 \mathrm{~h}$ and the half-life was $139 \pm 88 \mathrm{~h}$.
\end{abstract}

\section{INTRODUCTION}

Heterocysts are the primary site of nitrogen fixation in Anabaena and many other filamentous blue-green algae (cyanobacteria) under aerobic conditions. These cell types are generally absent from cultures of cyanobacteria grown in a medium containing ammonia, but develop and become functional within 24 to $36 \mathrm{~h}$ after transfer to nitrogen-free medium (Talpasayi \& Kale, 1967). Since lack of nitrogen in some way triggers heterocyst development, we have investigated the effects of nitrogen deprivation on protein metabolism to determine how protein synthesis and degradation are altered during the period coincident with heterocyst formation.

Protein turnover has been studied extensively in a variety of organisms (for reviews, see Huffaker \& Peterson, 1974; Goldberg \& St John, 1976). In bacteria, the degradation of total cell protein is very low in growing cells, $0.6 \% \mathrm{~h}^{-1}$ (Willetts, 1967), but may increase to 4 to $5 \% \mathrm{~h}^{-1}$ in nutrient-starved cells (Mandelstam, 1958) and to 8 to $10 \% \mathrm{~h}^{-1}$ in sporulating cells (Mandelstam \& Waites, 1968). The enhanced rate of protein breakdown apparently results from the activity of proteolytic enzymes synthesized during starvation (Doi, 1972). A similar system seems to exist in cyanobacteria. Lau et al. (1977) have reported increased degradation of phycocyanin, which may function as a storage protein, in nitratestarved Anacystis nidulans, while proteases which hydrolyse phycocyanin have recently been described in species of Anabaena (Wood \& Haselkorn, 1976; Foulds \& Carr, 1977).

We have induced nitrogen starvation and heterocyst formation in ammonia-grown Anabaena 7120 by transferring the organism to nitrogen-free medium and by treatment with the amino acid analogue L-methionine-DL-sulphoximine (MSO). MSO has previously been shown to initiate heterocyst development in several species of Anabaena (Stewart \& 
Rowell, 1975; Ownby, 1977). It apparently acts by irreversible inactivation of glutamine synthetase, the first enzyme in the pathway of assimilation of ammonia in cyanobacteria (Thomas et al., 1975). Since the use of MSO permits rapid induction of functional heterocysts without physical manipulation (e.g., centrifugation or filtration), it may be useful in fermenter or chemostat studies of heterocyst development.

\section{METHODS}

Growth conditions. The origin and growth of Anabaena 7120 have been described previously (Ownby, 1977). Briefly, cultures essentially free of heterocysts were obtained by growing Anabaena 7120 on a reciprocating shaker without aeration in the medium of Allen \& Arnon (1955) supplemented with 2 mM$\mathrm{NH}_{4} \mathrm{Cl}$ and $1 \mathrm{~mm}-\mathrm{NaNO}_{3}$. Nitrogen starvation and heterocyst development were initiated by adding MSO to a final concentration of $1 \mu \mathrm{M}$ or by transferring the cells to Allen \& Arnon's nitrogen-free medium after centrifuging at $480 \mathrm{~g}$ and rinsing once in nitrogen-free medium.

Measurement of protein synthesis. Samples $(18 \mathrm{ml})$ of Anabaena 7120 grown as above were transferred to $50 \mathrm{ml}$ flasks and allowed to grow for $24 \mathrm{~h}$. Half the flasks were then treated with $1 \mu \mathrm{M}$-MSO. After $0,2,5,11$ or $23 \mathrm{~h}$ of treatment, selected flasks were pulse-labelled for $1 \mathrm{~h}$ with $\left[4,5-{ }^{3} \mathrm{H}\right]$ leucine (New England Nuclear, 40 to $60 \mathrm{Ci} \mathrm{mmol}^{-1}$ ) at 0.027 or $0.135 \mu \mathrm{Ci} \mathrm{ml}^{-1}$ in $0.1 \mathrm{~mm}$ carrier leucine. At the end of the labelling period, the filaments in each flask were collected by centrifugation, resuspended in cold $6 \%(w / v)$ trichloroacetic acid (TCA), sonicated for $20 \mathrm{~s}$ (Branson sonifier model 185; Branson Sonic Power Co., Danbury, Conn., U.S.A.) and chilled for $30 \mathrm{~min}$. The TCA-insoluble fraction was collected by centrifuging, rinsed in cold TCA and dissolved in warm $0.5 \mathrm{M}-\mathrm{NaOH}$. The radioactivity in the medium, TCA-soluble fraction and TCAinsoluble, alkali-soluble fraction was measured by liquid scintillation spectrometry by placing $0.2 \mathrm{ml}$ of each fraction directly into a dioxan-based counting medium. The ${ }^{3} \mathrm{H}$ counting efficiency was approximately $40 \%$ in $6 \% \mathrm{TCA}$ and $43 \%$ in $0.5 \mathrm{M}-\mathrm{NaOH}$. In this and all subsequent experiments, measurements of total protein in the TCA-insoluble, alkali-soluble fraction were made using the method of Lowry et al. (1951).

Measurement of the release of ${ }^{3} \mathrm{H}$ from previously labelled protein. Anabaena 7120 was grown in the presence of fixed nitrogen in $11 \mathrm{flasks}$ for 3 to $4 \mathrm{~d}$, then labelled for $24 \mathrm{~h}$ with $60 \mu \mathrm{Ci}$ of $\left[{ }^{3} \mathrm{H}\right]$ leucine in $0 \cdot 1 \mathrm{~mm}$ carrier leucine. The filaments were collected by centrifuging and resuspended in unlabelled medium for a 14 to $15 \mathrm{~h}$ chase period, during which time much of the remaining soluble $\left[{ }^{3} \mathrm{H}\right]$ leucine was incorporated into protein (Halvorson, 1958). The cells were again collected by centrifuging, rinsed in the appropriate medium and resuspended in medium containing $\mathrm{NH}_{3}$, medium lacking nitrogen or medium containing MSO. All media contained $0.1 \mathrm{~mm}$ carrier leucine during the experimental period. Samples $(4 \mathrm{ml})$ were taken $0,2,4,8,12$ and $24 \mathrm{~h}$ after the initiation of nitrogen starvation, and ${ }^{3} \mathrm{H}$ in the medium, TCA-soluble and TCA-insoluble, alkali-soluble fractions was determined as described above.

Chromatography of ${ }^{3} \mathrm{H}$-labelled compounds. Samples $(0.2 \mathrm{ml})$ from the TCA-soluble fractions collected after $12 \mathrm{~h}$ of MSO-induced nitrogen starvation were spotted on MN300 cellulose plates and chromatographed in butan-1-ol/acetic acid/water (90:10:29, by vol.) for $4 \mathrm{~h}$. Sections of the chromatogram were analysed for ${ }^{3} \mathrm{H}$ by placing them directly into $10 \mathrm{ml}$ scintillation fluid containing $4 \mathrm{~g}$ 2,5-diphenyloxazole $\mathrm{l}^{-1}$ and $50 \mathrm{mg}$ 1,4-di-2-(5-phenyloxazolyl)benzene $1^{-1}$. The ${ }^{3} \mathrm{H}$ counting efficiency was 18 to $22 \%$ under these conditions.

Amino acid analysis. Anabaena 7120 was grown to exponential phase in 11 flasks and treated with MSO at $1 \mu \mathrm{M}$. After $0,2,4,6,8$ and $12 \mathrm{~h}, 25 \mathrm{ml}$ samples were taken and the filaments were collected by centrifugation. Free amino acids were released from the cyanobacteria by placing the cells in boiling water for 5 min. After removal of insoluble debris by centrifugation, the hot water-extractable fraction was filtered and lyophilized. Amino acids were redissolved in $0.3 \mathrm{ml}$ of pH 2.2 diluting buffer (Moore \& Stein, 1954) and assayed using an amino acid analyser modified for narrow bore columns (Liao et al., 1973).

\section{RESULTS}

All experiments were conducted with axenic cultures in the middle to late phase of exponential growth, during which the doubling time for total cell protein varied from 15 to $21 \mathrm{~h}$. Cyanobacteria treated with MSO or transferred to nitrogen-free medium ceased to accumulate protein after approximately 2 to $4 \mathrm{~h}$ (Fig. 1). After a lag period of 16 to $20 \mathrm{~h}$, cells in nitrogen-free medium once more began to accumulate protein coincident with the reported onset of nitrogen-fixing activity in Anabaena cylindrica whose doubling time is 


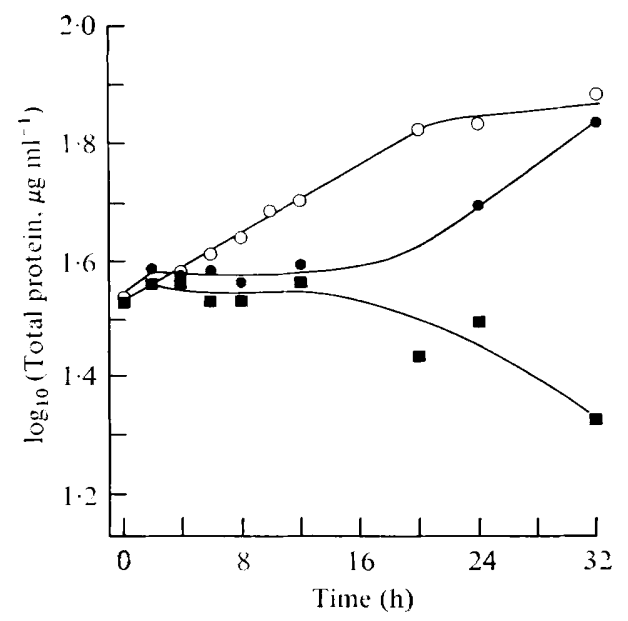

Fig. 1. Effect of nitrogen deprivation on accumulation of cell protein in Anabaena 7120. At zero time, filaments were transferred to medium containing $1 \mu \mathrm{M}$-MSO ( $\mathbf{m})$, medium lacking nitrogen (O) or medium containing $2 \mathrm{~mm}-\mathrm{NH}_{4} \mathrm{Cl}$ and $1 \mathrm{~mm}-\mathrm{NaNO}_{3}(\bigcirc)$. Each point is the average of at least three experiments.

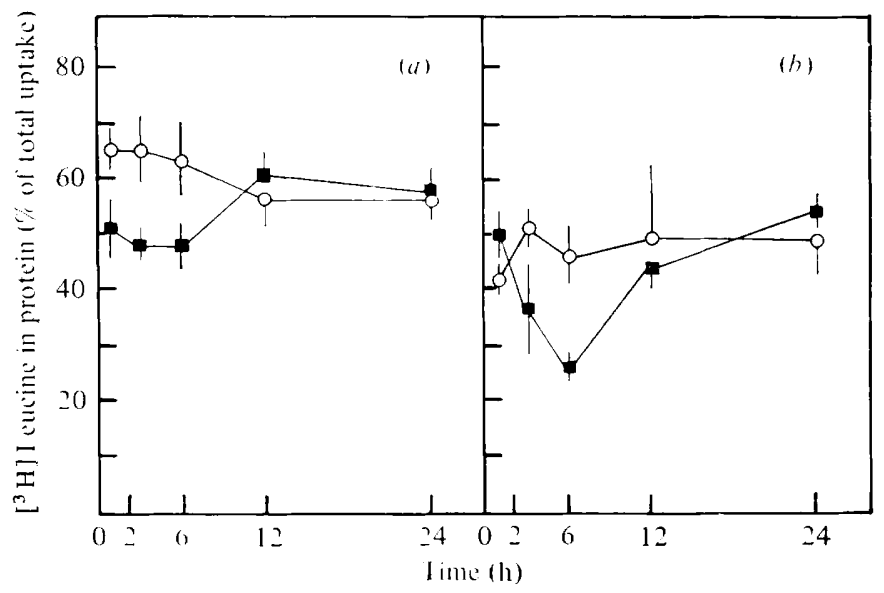

Fig. 2. Incorporation of $\left[{ }^{3} \mathrm{H}\right]$ leucine into protein in control (ammonia-grown) cultures $(C)$ and MSO-treated cultures ( $\square$ ) of Anabaena 7120 . Cultures were labelled with $\left[{ }^{3} \mathrm{H}\right]$ leucine at $0.027 \mu \mathrm{Ci}$ $\mathrm{ml}^{-1}(a)$ or $0 \cdot 135 \mu \mathrm{Ci} \mathrm{ml}{ }^{-1}(b)$ for $1 \mathrm{~h}$ at various times after treatment with MSO (zero time).

similar to that of Anabaena 7120 used in these experiments (Bradley \& Carr, 1976). Because of their apparent inability to assimilate $\mathrm{NH}_{3}$, MSO-treated cyanobacteria showed no accumulation of protein even after heterocysts had developed (see also Stewart \& Rowell, 1975).

The slow rate of uptake of radioactive precursors hinders metabolic studies in cyanobacteria. In the presence of carrier leucine at $0 \cdot 1 \mathrm{~mm}$ which apparently facilitates uptake by active transport systems ( $R$. Haselkorn, personal communication), the initial uptake of $\left[{ }^{3} \mathrm{H}\right]$ leucine by Anabaena 7120 was 8 to $12 \% \mathrm{~h}^{-1}$. We pulse-labelled cells for $1 \mathrm{~h}$ at intervals during the first $24 \mathrm{~h}$ of MSO-induced nitrogen starvation and expressed protein synthesis as a percentage of the total ${ }^{3} \mathrm{H}$ incorporated into protein (Fig. 2). To minimize the possibility that uptake rather than synthesis might limit the appearance of $\left[{ }^{3} \mathrm{H}\right] l e u c i n e$ in protein, we labelled cultures at $0.027 \mu \mathrm{Ci} \mathrm{ml} l^{-1}$ and $0.135 \mu \mathrm{Ci} \mathrm{ml}^{-1}$ and expressed the results separately (Fig. $2 a, b$ ). Although MSO had no effect on $\left[{ }^{3} \mathrm{H}\right]$ leucine uptake, the incorporation of ${ }^{3} \mathrm{H}$ 

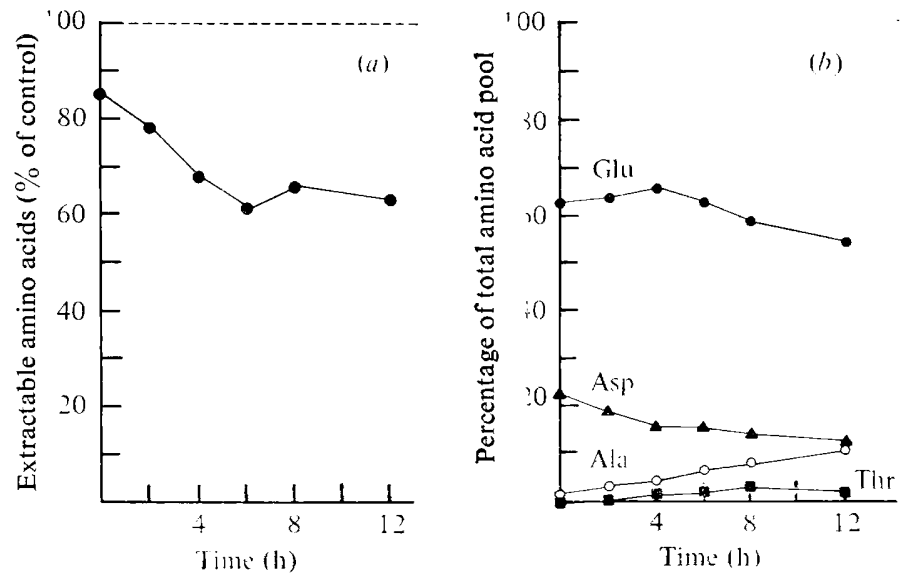

Fig. 3. Effect of MSO-induced nitrogen starvation on $(a)$ total hot water-extractable amino acids and $(b)$ relative abundance of major amino acids in the hot water-extractable pool of nitrogenstarved cells. In control (ammonia-grown) cultures. the level of free amino acids was $393 \mathrm{nmol}$ $(\mathrm{mg} \text { protein })^{-1}$ initially, and $288 \mathrm{nmol}(\mathrm{mg} \text { protein })^{-1}$ after $12 \mathrm{~h}$.
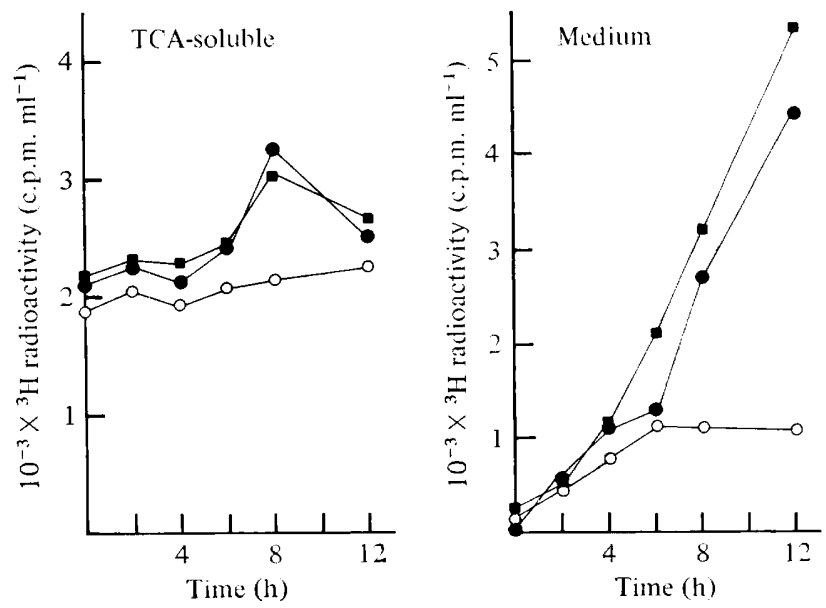

Fig. 4. Release of ${ }^{3} \mathrm{H}$ from protein in cultures of Anabaena 7120 previously labelled with [ $\left.{ }^{3} \mathrm{H}\right]$ leucine for $24 \mathrm{~h}$ and then transferred to medium containing $1 \mu_{\mathrm{M}}$-MSO (a), nitrogen-free medium (O)

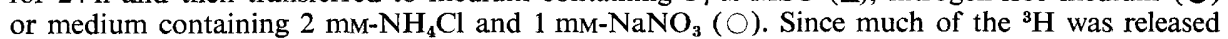
into the culture medium, all values have been expressed as c.p.m. (ml culture) ${ }^{-1}$. At zero time, the ${ }^{3} \mathrm{H}$ in the TCA-insoluble fraction was 10364 c.p.m. (ml culture) ${ }^{-1}$.

into TCA-insoluble material was only 50 to $70 \%$ of that in control cultures during the first $6 \mathrm{~h}$, but subsequently the rate returned to that of ammonia-grown cultures after 12 and $24 \mathrm{~h}$.

The initial decline in protein synthesis in MSO-treated cultures was in general matched by a decrease in the levels of hot water-extractable amino acids during the first $6 \mathrm{~h}$ of treatment (Fig. $3 a$ ). MSO-treated cultures also showed changes in amino acid composition, most notably a decline in aspartic acid matched by an increase in alanine (Fig. $3 b$ ). Threonine and tyrosine, which were not detectable at zero time, increased to $2.3 \%$ and $1.4 \%$, respectively, of the total amino acid pool after $12 \mathrm{~h}$.

We measured protein degradation by the release of ${ }^{3} \mathrm{H}$ from proteins previously labelled with $\left[{ }^{3} \mathrm{H}\right]$ leucine, since Halvorson (1958) has shown that this approach provides a clearer index of protein degradation than when the decline of ${ }^{3} \mathrm{H}$ in protein is measured directly. 

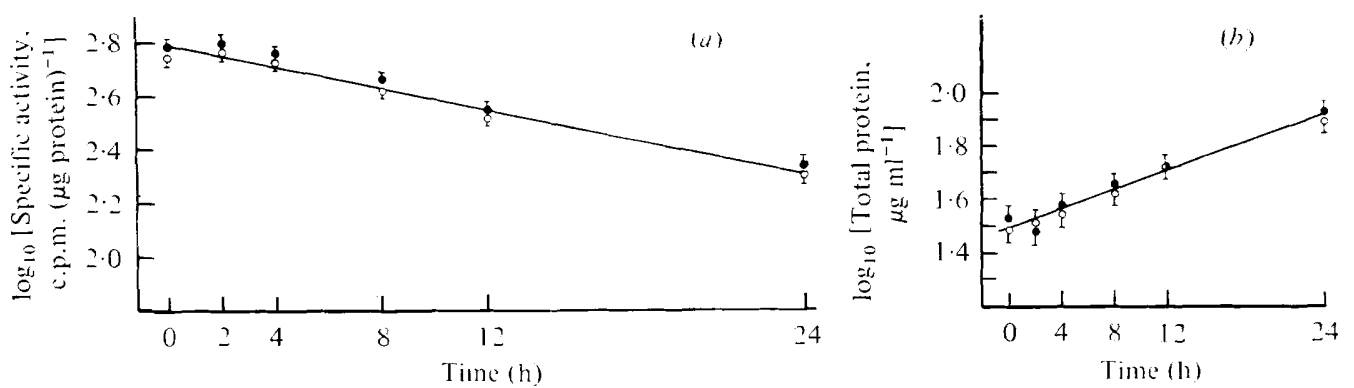

Fig. 5. (a) Change in specific activity of ${ }^{3} \mathrm{H}$-labelled protein from ammonia-grown Anabaena 7120 after transfer to unlabelled medium. The cells were labelled for $24 \mathrm{~h}$ with $\left[{ }^{3} \mathrm{H}\right] l e u c i n e[60 \mu \mathrm{Ci}(200$ $\mathrm{ml}$ medium $)^{-1}$, and sampled after a subsequent $16 \mathrm{~h}$ chase period. $O$, Culture flasks contained $0.1 \mathrm{~mm}$ unlabelled leucine during the experimental period. $\bigcirc$, No unlabelled leucine was added to the culture flasks for the experimental period. (b) Accumulation of total cell protein during the experimental period.

\section{Table 1. Rate constants for synthesis and degradation of cyanobacterial protein during rapid growth}

Rate constants $\left(\mathrm{d}^{-1}\right)$ were obtained by multiplying the slopes obtained as in Fig. 5 by $\log _{\mathrm{e}} 10 \times 24$. Doubling time and half-life were determined by dividing $\log _{e} 2$ by the rate constants for synthesis and degradation, respectively.

\author{
Rate constant for synthesis \pm S.D. \\ Rate constant for accumulation \pm S.D. \\ Rate constant for degradation \pm S.D. \\ Doubling time \\ Half-life
}

$$
\begin{aligned}
& 1 \cdot 12 \pm 0.07 \mathrm{~d}^{-1} \\
& 1 \cdot 00 \pm 0.09 \mathrm{~d}^{-1} \\
& 0 \cdot 12 \pm 0.08 \mathrm{~d}^{-1} \\
& 14.9 \pm 1.0 \mathrm{~h} \\
& 139 \pm 88 \mathrm{~h}
\end{aligned}
$$

During the initial $24 \mathrm{~h}$ labelling period, the specific activity of cell protein reached $384 \pm$ 19 c.p.m. ( $\mu$ g protein $)^{-1}$. In the subsequent $16 \mathrm{~h}$ chase period, the percentage of ${ }^{3} \mathrm{H}$ in the TCA-insoluble fraction increased from 64 to $88 \%$ of the total cellular $\left[{ }^{3} \mathrm{H}\right]$ leucine. At the end of the chase period, the specific activity of total cell protein was $348 \pm 40$ c.p.m. ( $\mu \mathrm{g}$ protein $)^{-1}$. The release of ${ }^{3} \mathrm{H}$ into the medium and TCA-soluble fraction over the following $12 \mathrm{~h}$ was measured in cultures transferred to medium containing ammonia, medium lacking nitrogen or medium containing MSO (Fig. 4). Although the TCA-soluble fraction (including free amino acids) underwent a transient increase 4 to $8 \mathrm{~h}$ after treatment, the major effect of nitrogen starvation was to stimulate release of ${ }^{3} \mathrm{H}$ into the medium, particularly in the period 4 to $12 \mathrm{~h}$ after treatment began. During this time, the rate of protein breakdown, as measured by release of ${ }^{3} \mathrm{H}$, was 6 to $7 \cdot 5$ times greater in nitrogen-starved than in control (ammonia-grown) cultures.

To establish whether the ${ }^{3} \mathrm{H}$ released from labelled proteins was still in the form of leucine, we chromatographed $200 \mu \mathrm{l}$ samples from the medium and the TCA-soluble fraction as described in Methods. With cyanobacteria grown in fixed-nitrogen medium, $67 \%$ of the TCA-soluble ${ }^{3} \mathrm{H}$ and $57 \%$ of the ${ }^{3} \mathrm{H}$ released to the medium after $12 \mathrm{~h}$ co-chromatographed with authentic leucine. By contrast, only $27 \%$ of the TCA-soluble ${ }^{3} \mathrm{H}$ and $9 \%$ of the ${ }^{3} \mathrm{H}$ released into the medium by nitrogen-starved cyanobacteria appeared as leucine.

Since synthesis and degradation of protein in exponentially growing cultures should be linear with time, we attempted to determine rate constants for these processes under conditions of rapid growth. The general approach used, and the assumptions on which it is based, have been described by Trewavas (1972). The method involved obtaining rate constants for protein accumulation from the slope of a graph of $\log _{10}$ total protein plotted against time and the rate constants for protein synthesis from the slope of a graph of $\log _{10}$ specific activity of protein plotted against time, using cultures in which the proteins had been previously labelled with $\left[{ }^{3} \mathrm{H}\right]$ leucine. The rate constants for degradation were calculated as 
the difference between rate constants for synthesis and rate constants for accumulation. The accumulation of protein and decline in specific activity of proteins previously labelled with $\left[{ }^{3} \mathrm{H}\right]$ leucine are shown in Fig. 5. Growth constants calculated from these results are shown in Table 1. Although Scherer \& Boylen (1977) showed that 0.1 mM excess unlabelled leucine was effective in preventing the recycling of $\left[{ }^{3} \mathrm{H}\right]$ leucine into new protein in Arthrobacter, we observed no difference in the decline in specific activity when $0.1 \mathrm{~mm}$-leucine was added to cultures during the experimental period. The growth constants shown in Table 1 have thus been calculated using both cultures without carrier leucine and those to which $0 \cdot 1 \mathrm{~mm}$ unlabelled leucine had been added.

\section{DISCUSSION}

Two factors which may contribute to erroneous estimates of protein turnover rates are release of proteins through cell death and recycling of amino acids from hydrolysed proteins into new proteins. The contribution of cell death to protein turnover has not been determined, although microscopic examination of rapidly growing cultures showed very few dead cells or cell fragments. Since the addition of excess unlabelled leucine had no detectable effect on the decline in specific activity of previously labelled proteins, the rate of recycling of amino acids into new proteins also appears to be small. In the absence of data on the rate of re-utilization of $\left[{ }^{3} \mathrm{H}\right]$ leucine, however, our estimates are best taken as the minimum rates of synthesis and degradation. Another possibility which might explain the relatively rapid rate of protein catabolism in Anabaena 7120 compared with eubacteria is that Anabaena 7120 secretes proteins into the medium, which would result in an overestimated rate of degradation. We did observe, however, that over half $(57 \%)$ of the ${ }^{3} \mathrm{H}$ in the medium chromatographed as the free amino acid leucine.

The data on amino acid levels and incorporation of $\left[{ }^{3} \mathrm{H}\right]$ leucine into protein indicate that the first $6 \mathrm{~h}$ of nitrogen starvation are marked by a reduced capacity for protein synthesis. It should be noted, however, that at no time did protein synthesis fall below 50 to $70 \%$ of that in control (ammonia-grown) cultures. This suggests that neither depletion of amino acid pools nor total cessation of protein synthesis are characteristic of the period when heterocysts probably start to develop. Fleming \& Haselkorn (1976), also working with Anabaena 7120 , reported that the incorporation of ${ }^{35} \mathrm{~S}$ into protein decreased continuously to $10 \%$ of the initial rate during the first 27 to $36 \mathrm{~h}$ of heterocyst development.

The data showing active release of ${ }^{3} \mathrm{H}$ from previously labelled proteins and increased incorporation of pulse-labelled $\left[{ }^{3} \mathrm{H}\right]$ leucine into new proteins suggest that cyanobacteria rapidly degrade proteins and utilize the amino acids in the synthesis of new proteins 6 to $24 \mathrm{~h}$ after the onset of nitrogen starvation. The major form of protein hydrolysed is probably phycocyanin. Bradley \& Carr (1976) have shown that phycocyanin declines to $10 \%$ of its initial level in Anabaena cylindrica during the first $18 \mathrm{~h}$ of nitrogen starvation, and cell-free extracts from Anabaena cylindrica contain an active, specific phycocyaninase (Foulds \& Carr, 1977).

Very little of the ${ }^{3} \mathrm{H}$ released from protein in nitrogen-starved cultures remains in leucine. It appears that amino acids thus generated are extensively metabolized, including perhaps deamination and release of carbon skeletons into the medium. Newman et al. (1976) observed that Escherichia coli grown on leucine as the sole nitrogen source caused the release of nitrogen from leucine and excretion of $\alpha$-ketoisocaproic acid into the medium.

Do the changes in protein turnover reported here bear any direct relation to heterocyst development? Much of the protein degraded and later resynthesized is probably confined to vegetative cells and plays no role in the formation and regulation of heterocysts [i.e. proteins in classes $\mathrm{g}, \mathrm{h}$, and $\mathrm{i}$ in the model of Fleming \& Haselkorn (1974)]. A means by which protein catabolism could regulate heterocyst development, however, would be one in which proteinaceous inhibitors that repress heterocyst development are degraded and not resynthesized during the first $6 \mathrm{~h}$, permitting the expression of genes involved in hetero- 
cyst formation. Later resynthesis of the inhibitors, using amino acids from degraded storage proteins, would prevent further commitment of cells to heterocysts. Mandelstam \& Waites (1968) proposed a role for proteinaceous inhibitors in Bacillus subtilis spore development. Another possibility is that the products of proteolysis inhibit the commitment of cells to heterocysts, as suggested by Fleming \& Haselkorn (1974).

Our results show that, in addition to co-ordinated changes in morphological development, Anabaena 7120 undergoes marked changes in protein metabolism during nitrogen starvation. The possible interactions between these two processes need to be investigated further.

This work was supported by National Science Foundation Grant PCM76-81662. The amino acid determinations were performed by $\mathrm{Dr} \mathrm{T}$. Liao, Department of Biochemistry, Oklahoma State University. The technical assistance of Susan Armour is gratefully acknowledged.

\section{REFERENCES}

Allen, M. B. \& Arnon, D. I. (1955). Studies on nitrogen-fixing blue-green algae. 1. Growth and nitrogen fixation by Anabaena cylindrica Lemm. Plant Physiology 30, 366-372.

Bradley, S. \& Carr, N. G. (1976). Heterocyst and nitrogenase development in Anabaena cylindrica. Journal of General Microbiology 96, 175-184.

DoI, R. H. (1972). Role of proteases in sporulation. Current Topics in Cellular Regulation 6, 1-18.

Fleming, H. \& HASELKoRn, R. (1974). The program of protein synthesis during heterocyst differentiation in nitrogen-fixing blue-green algae. Cell $\mathbf{3}$, 159-170.

Foulds, I. J. \& Carr, N. G. (1977). A proteolytic enzyme degrading phycocyanin in the cyanobacterium Anabaena cylindrica. FEMS Microbiology Letters 2, 117-119.

GoldberG, A. L. \& St JoHn, A. C. (1976). Intracellular protein degradation in mammalian and bacterial cells: part 2. Annual Review of Biochemistry 45, 747-803.

HALvorson, H. (1958). Intracellular protein and nucleic acid turnover in resting yeast cells. Biochimica et biophysica acta 27, 255-266.

Huffaker, R. C. \& Peterson, L. W. (1974). Protein turnover in plants and possible means of its regulation. Annual Review of Plant Physiology 25, 363-392.

Lau, R. H., Mackenzie, M. M. \& Doolittle, W. F. (1977) Phycocyanin synthesis and degradation in the blue-green bacterium Anacystis nidulans. Journal of Bacteriology 132, 771-778.

Liao, T., Robinson, G. W. \& Salnikow, J. (1973). Use of narrow-bore columns in amino acid analysis. Analytical Chemistry 45, 2286-2288.

Lowry, O. H., Rosebrough, N. J., Farr, A. L. \& Randall, R. J. (1951). Protein measurement with the Folin phenol reagent. Journal of Biological Chemistry 193, 265-275.

Mandelstam, J. (1958). Turnover of protein in growing and non-growing populations of Escherichia coli. Biochemical Journal 69, 110-119.

Mandelstam, J. \& Waites, W. M. (1968). Sporulation in Bacillus subtilis. The role of exoprotease. Biochemical Journal 109, 793-801.
Moore, S. \& Stein, W. H. (1954). Procedures for the chromatographic determination of amino acids on four per cent cross-linked sulfonated polystyrene resins. Journal of Biological Chemistry 211, 893-906.

Newman, E. B., Adley, T., Fraser, J., Potter, R. \& Kapoor, V. (1976). The conversion of leucine to $\alpha$-ketoisocaproic acid and its metabolic consequences for Escherichia coli K12. Canadian Journal of Microbiology 22, 922-928.

OWNBY, J. (1977). Effects of amino acids on methionine sulfoximine-induced heterocyst formation in Anabaena. Planta 136, 277-279.

SCherer, C. G. \& Boylen, C. W. (1977). Macromolecular synthesis and degradation in Arthrobacter during periods of nutrient starvation. Journal of Bacteriology 132, 584-589.

Stewart, W. D. P. \& Rowell, P. (1975). Effects of L-methionine-DL-sulfoximine on the assimilation of newly fixed $\mathrm{NH}_{3}$, acetylene reduction, and heterocyst production in Anabaena cylindrica. Biochemical and Biophysical Research Communications 65, 846-856.

Talpasayi, E. R. S. \& Kale, K. S. (1967). Induction of heterocysts in the blue-green alga Anabaena ambigua. Current Science 36, 218-219.

Thomas, J., Wolk, C. P., Shaffer, P. W., Austin, S. M. \& Galonsky, A. (1975) The initial organic products of fixation of ${ }^{15} \mathrm{~N}$-labelled nitrogen gas by the blue-green alga Anabaena cylindrica. Biochemical and Biophysical Research Communications 67, 501-507.

Trewavas, A. (1972). Determination of the rates of protein synthesis and degradation in Lemna minor. Plant Physiology 49, 40-46.

WILlETTS, N. S. (1967). Intracellular protein breakdown in growing cells of Escherichia coli. Biochemical Journal 103, 462-466.

WoOd, N. B. \& HASElkoRn, R. (1976). Protein degradation during heterocyst development in Anabaena. In Proceedings of the Second International Symposium on Photosynthetic Prokaryotes, pp. 125-127. Edited by G. A. Codd \& W. D. P. Stewart. Dundee: University of Dundee Press. 